INTERNATIONAL DESIGN CONFERENCE - DESIGN 2018

https://doi.org/10.21278/idc.2018.0294

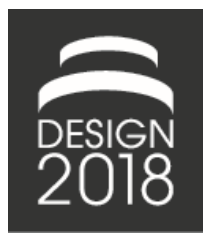

\title{
LEAN OFFICE: STUDY ON THE APPLICABILITY OF THE CONCEPT IN A DESIGN COMPANY
}

\author{
R. M. Sastre, T. A. Saurin, M. E. S. Echeveste, I. C. de Paula and R. Lucena
}

\begin{abstract}
This study has explored the applicability of the concepts related to Lean Manufacturing with focus on service areas, specifically in an office specialized in graphic design of packaging. Through a case study it was possible to deploy and analyse the value stream map of the company's overall processes. This map has assisted in identification of waste situations and in proposing improvements in the process. It is concluded that Lean concepts have been presented as promising in a graphic design company and are potentially applicable in creative companies.
\end{abstract}

Keywords: lean manufacturing, packing, design activities, design process, case study

\section{Introduction}

Being Lean implies a continuous effort to reach a state characterized by minimal waste and maximum flow. Becoming Lean requires a change of mindset, learning and facing change, continually increasing the visualization of waste and its elimination. Lean thinking is a way of doing more with less, less effort, less equipment, less time and less space, more and more approaching the ideal of meeting clients' needs and delivering exactly what they want (Tapping and Shuker, 2010; Evangelista et al., 2015).

The need for companies to become increasingly efficient or "lean" in order to survive in a competitive and borderless market, there is a need to implement the Lean principle, not only in manufacturing processes, but also in offices and industry sectors services, where it is called 'Lean Office'. Although there are publications about Lean Office in different environments such as hospitals, public and administrative areas, design offices are not so frequent. From the opportunity of application in this type of office emerges the following question: what would be the peculiarities of the implantation of lean office in a design office?

This study explored the applicability of concepts related to Lean Manufacturing with focus on administrative or service areas, specifically in an office specialized in graphic design of packaging. The theoretical contribution was the proposition and the use of systemic tools to promote improvements in an office that works in the area of creativity, which seemed unlikely. The practical contribution was not only to apply them but also to check the benefits of reducing waste and suggesting improvements in the process.

\section{Literature review}

This session will introduce Lean Manufacturing (Lean Manufacturing), Lean Office (Lean Office), and the tools used to deploy Lean Office in offices and service providers. These concepts serve as the basis for the case study proposed in a graphic design firm. 


\subsection{Lean Manufacturing}

"Quality" evolution patterns as a management science have been significant throughout history. From the first decade after World War II, the quality movement has progressed towards becoming efficient in the processes and operations management by focusing clients. In this period, in Japan, the emergence of the Toyota Production System (TPS), defined as a philosophy that resulted from a dynamic learning process adapted to the practices of the textile and automotive sectors, gave rise to what is called Lean Management or Lean Production, in response to production, economic and environmental challenges (Danielsson, 2013; Vidolin, 2015; Gupta et al., 2016).

Ohno (1997) has identified seven types of waste that may have an impact on a productive system, away from the ideal Lean concept. They are: i) Overproduction: Overproducing or before need; ii) Waiting: Idle periods of people, parts and information, with long lead times; iii) Excessive transportation: Excessive movement of people, information or parts, producing unnecessary expenditure of capital, time and energy; iv) Inadequate processes: Use of wrong tools, systems or procedures; v) Unnecessary inventory: Excessive storage and lack of information or products, resulting in excessive costs and poor performance of client service; vi) Unnecessary movement: Disorganization of the work environment, resulting in low performance of the ergonomic aspects and frequent loss of items; and vii) Defective products: Product quality problems or poor performance in delivery (Evangelista et al., 2015; Hallam and Contreras, 2016).

Below are the concepts of Lean Offices.

\subsection{Lean Office}

Lean Manufacturing concepts were developed from the manufacturing area and have been practiced in recent years in productive areas with positive results due to companies' needs to become leaner. These concepts have real conditions of being applied in non-productive areas, which is defined as Lean Office when applied in administrative areas, aiming at eliminating elements that do not add value to their processes, reducing time, waste and having greater quality in meeting clients' needs (Evangelista et al., 2015; Vidolin, 2015).

The Lean Office concept adheres to the flow of information that does not follow material or manufacturing processes. Therefore it prioritizes the maintenance of objectives related to cost reduction, elimination of rework, minimization of communication problems, reduction and elimination of activities that do not add value to processes, increasing productivity, efficiency of administrative functions and better use of the work area in administrative environments, producing more and more quality. The Lean concept overall goal is to free up time and provide more efficient work. This is done by creating a better workflow, visualizing order, reducing deadlines and waste, implementing continuous improvements and increasing flexibility (Womack and Jones, 2005; Lopes, 2011; Vidolin, 2015). With special attention to administrative and services sectors, Lareau (2002) lists the 30 waste situations classified in administrative processes (Table 1).

The same seven types of waste described in manufacturing (previous Section of this article) can be found in administrative sectors: overproduction; waiting time; excessive transportation; inadequate processes; unnecessary inventory; unnecessary movement; and defective products (Evangelista et al., 2015). Waste mentioned in this Section shall be observed and analyzed in the case study through the use of some tools described in the topic below.

Table 1. 30 waste situations in administrative processes

\begin{tabular}{|l|l|}
\hline \multicolumn{1}{|c|}{ Waste } & \multicolumn{1}{c|}{ Cause } \\
\hline $\begin{array}{l}\text { Aligning } \\
\text { objectives }\end{array}$ & $\begin{array}{l}\text { Energy expended with work on objectives misunderstood, in addition to the effort to } \\
\text { correct the problem and produce the desired result. }\end{array}$ \\
\hline Assignment & Commitment to complete an unnecessary task. \\
\hline Waiting time & Time wasted by people waiting for information, meetings etc. \\
\hline Movement & It is the energy lost in unnecessary movement. \\
\hline Processing & Activity performed without quality. \\
\hline
\end{tabular}




\begin{tabular}{|c|c|}
\hline Control & $\begin{array}{l}\text { It is the vigor used to monitor and verify that it does not provide performance } \\
\text { improvements. }\end{array}$ \\
\hline Variability & It is the means used to compensate or correct results other than those expected. \\
\hline Amendment & $\begin{array}{l}\text { It is the energy used to change the process with ignorance of results and the efforts to } \\
\text { compensate for unexpected results. }\end{array}$ \\
\hline Strategy & $\begin{array}{l}\text { It is the value consumed in implementing processes that meet short-term objectives. } \\
\text { However, clients and investors have no value added to them. }\end{array}$ \\
\hline Reliability & $\begin{array}{l}\text { It is the effort required to correct results that can not be predicted due to unknown } \\
\text { causes. }\end{array}$ \\
\hline Standardization & It is the effort employed in a job that is not performed in the best possible way. \\
\hline Suboptimization & $\begin{array}{l}\text { It is the result of the rivalry of two processes, duplicate work, compromising the } \\
\text { processes and the quality of the final result. }\end{array}$ \\
\hline Schedule & It is the use without schedule quality. \\
\hline $\begin{array}{l}\text { Informal } \\
\text { processes }\end{array}$ & $\begin{array}{l}\text { It is the lack of the practice of official processes that are replaced by informal } \\
\text { processes or that create conflicts with other informal processes, in addition to } \\
\text { resources used to correct errors caused by this system. }\end{array}$ \\
\hline Irregular flow & $\begin{array}{l}\text { It is every resource used, either with materials or information, that accumulate among } \\
\text { the work stages, providing irregular flow. }\end{array}$ \\
\hline $\begin{array}{l}\text { Unnecessary } \\
\text { checks }\end{array}$ & It is the energy used to inspect and do rework. \\
\hline Errors & The product of works that could not be used. \\
\hline Translation & $\begin{array}{l}\text { It is the effort to change data, reports and formats during the process or those } \\
\text { responsible for them. }\end{array}$ \\
\hline Lost information & $\begin{array}{l}\text { Means are used to restore or compensate for the results of the lack of standard } \\
\text { information. }\end{array}$ \\
\hline $\begin{array}{l}\text { Lack of } \\
\text { integration }\end{array}$ & $\begin{array}{l}\text { It is the work required to convey information within the organization that is not } \\
\text { interconnected to the network of processes employed. }\end{array}$ \\
\hline Irrelevance & $\begin{array}{l}\text { It is the energy used to work with unnecessary information or energy to fix problems } \\
\text { caused because of this. }\end{array}$ \\
\hline Inaccuracy & $\begin{array}{l}\text { It is the effort used to generate incorrect information or to repair the results of this } \\
\text { situation. }\end{array}$ \\
\hline Inventory & $\begin{array}{l}\text { Resources used in a service before it is requested or materials not being used or all } \\
\text { materials that are already ready for delivery and are in waiting. }\end{array}$ \\
\hline $\begin{array}{l}\text { Secondary } \\
\text { processes }\end{array}$ & $\begin{array}{l}\text { Resources consumed in secondary processes that can not yet be used in the subsequent } \\
\text { steps of the process. }\end{array}$ \\
\hline $\begin{array}{l}\text { Underutilized } \\
\text { assets }\end{array}$ & Resources such as equipment and facilities that are not used in their entirety. \\
\hline Transportation & $\begin{array}{l}\text { It encompasses all transportation of materials and information, not including those } \\
\text { used to deliver products and/or services to clients. }\end{array}$ \\
\hline Lack of focus & Employees' energy and attention are not directed to the organization's objectives. \\
\hline Structure & $\begin{array}{l}\text { When procedures, behaviors, regulations, positions and priorities are not targeted } \\
\text { towards reducing waste. }\end{array}$ \\
\hline Domain & When the coverage area of employees' work is increased and not employed. \\
\hline Subject & $\begin{array}{l}\text { It occurs when there is lack of responsibility, system failure and problems related to } \\
\text { employees' discipline. }\end{array}$ \\
\hline
\end{tabular}

Font: Adapted from Vidolin (2015) 


\subsection{Lean method tools applied to offices}

The concepts of the Lean philosophy expose practical tools that help companies and managers turn them into Lean ones. The techniques and tools used by the Lean principles are derived from the Lean Production concept originated after World War II with the implementation of the Toyota Production System (TPS). It is a management philosophy that seeks efficiency with cost reduction through a new rationalization of activities and optimization of people in the form of developing their tasks (Womack and Jones, 2005).

Among the main Lean techniques and Lean tools, stand out: The 5S workplace organization method; standardized work; work cells; visual management; value stream mapping; FIFO (First In-First Out) method; just-in-time (JIT) methodology; continuous flow; pull flow; Kanban scheduling system; Takt time (the average time between the start of production of one unit and the start of production of the next unit); Jidoka (automation with a human touch); Heijunka (leveling production); Kaizen (activities that continuously improve all functions); (iterative interrogative technique) 5 Whys; A3 structured problem solving and continuous improvement approach and source quality (Cavaglieri and Juliani, 2016a).

According to Ohno (1997), production based on the just-in-time (JIT) methodology system requires that each process receive the material demanded, in the correct quantity and when it is demanded. Thus the Toyota Production System (TPS) is initiated, focusing on elimination of waste and production of only the products demanded at the precise time and quantity (Vidolin, 2015). Importantly, the Lean principles are not just a set of tools and techniques but people are in their core. People whose knowledge, intelligence and desire to improve guide organizations to new levels of continuous improvement (Saurin et al., 2011; Bhasin, 2012).

Respect for people in the Lean philosophy is an important element. And respect begins when one thinks of Lean commitment to the company by means of information and calling all to participate because all are equally important within the system (Vidolin, 2015). In this way, the human component is perhaps one of the most important supporting components of the Lean philosophy. Respect for human beings comprises providing training, technical information and quality physical conditions for their development. People with self-management power are co-responsible authors by actions and processes (Cavaglieri and Juliani, 2016a).

The application of the Lean Office can be extended to any administrative sector as an example of public organizations, as they can help public services to provide more quality services delivered to their citizen clients, as well as to make them more agile and encourage transparency in activities (Turati, 2006).

Following strategies similar to those used in Lean Production, the administrative and service sectors can also become Lean. However, there is no step-by-step recipe for this transformation and each company can follow a different path to achieve this goal. Implementation of the Lean Office model uses some tools of the traditional method. Tapping and Shuker (2010) present models, concepts and tools frequently used in factories that can be transposed into administrative environments, (Table 2):

Table 2. Concepts and tools used in into administrative environments

\begin{tabular}{|l|l|}
\hline $\begin{array}{l}\text { Value stream } \\
\text { mapping (VSM) }\end{array}$ & $\begin{array}{l}\text { It is a planning tool that allows the information flow visualization in a } \\
\text { comprehensive way by creating maps (Silva et al., 2015). It is the process of } \\
\text { planning data recording and analyses according to the Lean philosophy of any } \\
\text { action that adds or not value demanded by a product in its full flow of raw } \\
\text { material through production until reaching the client, when one considers } \\
\text { productive processes (Vidolin, 2015). When talking about value, it is understood } \\
\text { by what is being created and that has some value to a client who is willing to pay. } \\
\text { The VSM helps in planning and linking Lean initiatives to achieve the future } \\
\text { state planned by means of systematic data capture and analysis, resulting in cost } \\
\text { reduction by eliminating waste and creating smooth flows of information and } \\
\text { work (Tapping and Shuker, 2003). }\end{array}$ \\
\hline
\end{tabular}




\begin{tabular}{|c|c|}
\hline $\begin{array}{l}\text { The } 5 \mathrm{~S} \text { workplace } \\
\text { organization method }\end{array}$ & $\begin{array}{l}\text { It is based on five Japanese words beginning with the letter S: SEIRI - Separating } \\
\text { required resources and disposing of unnecessary resources; SEITON - } \\
\text { Organizing necessary resources, facilitating access to them; SEISO - Maintaining } \\
\text { a high standard of cleanliness in the workplace, tools and equipment; SEIKETSU } \\
\text { - Ensuring the maintenance of the } 5 \text { S first } 3 \text { practices in a standardized way } \\
\text { throughout the organization; SHITSUIKE - Discipline and commitment to fulfill } \\
\text { the first } 4 \text { S of the tool (Ishizaka et al., 2016). The } 5 \text { S are a tool with great } \\
\text { potential of use in offices aiming to create some site that allows visual control } \\
\text { and execution of tasks in a Lean fashion. It allows work standardization and } \\
\text { greater control of workers in the site and their activities in order to reduce waste. } \\
\text { Each one of "these" motivates changes and discipline, which are critical to work } \\
\text { rationalization, simplifying tasks execution with greater visual control. }\end{array}$ \\
\hline Continuous flow & $\begin{array}{l}\text { It is a concept that allows information to flow among stages of the process } \\
\text { without stopping among them, thus eliminating bottlenecks and reducing } \\
\text { inventory information without the need to transport people among such steps } \\
\text { (Tapping and Shuker, 2003). Work organized in cells, FIFO (First In-First Out) } \\
\text { lines, the Operator Balance Chart (OBC) with cycle time display and Takt time } \\
\text { are tools that help control activities and can show opportunities for improvement } \\
\text { (Tapping and Shuker, 2003). }\end{array}$ \\
\hline Standardized work & $\begin{array}{l}\text { It is a concept that means establishing and documenting the procedure that } \\
\text { provides the best results, with the best method and the best sequence of activities } \\
\text { to ensure that a task is always performed in the same way. The establishment of } \\
\text { best practices allows simple training of the personnel, enabling the execution of } \\
\text { more than one service and making the flow more flexible. A standardized process } \\
\text { should have the number of steps reduced. And value stream analysis helps in } \\
\text { identifying unnecessary activities and their wastes (Tapping and Shuker, 2003). } \\
\text { In a Lean Office, two specific visual tools are used in connection with this } \\
\text { concept: the Standardized Work Combination Table (SWCT) and the } \\
\text { Standardized Work Chart (SWC). The first one visually represents the workflow } \\
\text { related to the process in a given area, specifying the time required in each step } \\
\text { and including the transit and waiting times. It is also discriminated whether the } \\
\text { required processing is manual or automatic. The second tool is a chart that } \\
\text { displays the task sequence, that is, it is actually a working instruction sheet. It } \\
\text { should remain visible on the desktop and be updated when improvements are } \\
\text { implemented. Such a tool can include different types of items, such as forms, } \\
\text { checklists, desktop organization maps etc. (Ishizaka et al., 2016). }\end{array}$ \\
\hline Pull systems & $\begin{array}{l}\text { To perform the service with its result available at the correct time, it is necessary } \\
\text { to know the processes before and after this activity. Among the advantages of the } \\
\text { pull production it is possible to mention the reduction of processing time, of } \\
\text { stocks and queues and of stages and number of people involved, greater } \\
\text { production control and identification of problems and programming } \\
\text { improvements. }\end{array}$ \\
\hline Takt time & $\begin{array}{l}\text { It is the time determined by clients' demand, being therefore the rhythm imposed } \\
\text { to the workflow by this demand. To calculate it for a given value stream, simply } \\
\text { divide the number of daily work hours by the total work units required for a day, } \\
\text { discounting the intervals for meetings, lunches etc. }\end{array}$ \\
\hline Heijunka (leveling) & $\begin{array}{l}\text { It is a physical stratagem used to control the volume of service and its variety } \\
\text { within a certain period. It consists of a box with compartments where each } \\
\text { represents an increment, a unit of work that must be transferred to the next } \\
\text { activity. The goal is to level the workload so that people and resources are used in } \\
\text { the best possible way, also serving as an information center of what is occurring } \\
\text { in the flow (Tapping and Shuker, 2003). }\end{array}$ \\
\hline
\end{tabular}

Font: Tapping and Shuker (2010) 


\section{Methodology}

Process improvement and waste reduction can be accomplished through the use of the tools described above but this study has not addressed the $5 \mathrm{~S}$ due to emphasizing the workflow through other tools such as Value Stream Mapping (VSM) to view the flow of information comprehensively. As a result, proposing a future state map and a Kaizen plan, according to Tapping and Shuker (2003), means modifying processes to make them better.

In order to systematize the application of Lean Office tools in the object of study, the methodology proposed by Tapping and Shuker (2010) was chosen, to which it delimits in eight steps for the implantation and maintenance of a Lean Office (Figure 1).

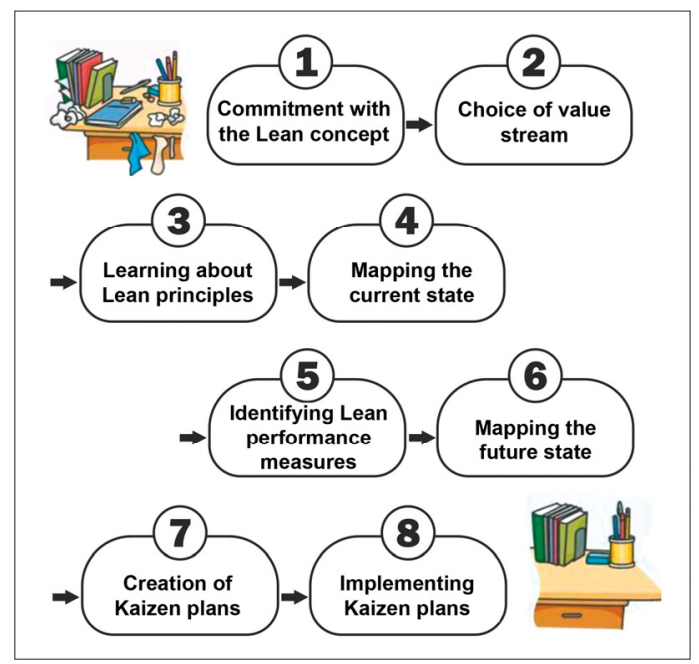

Figure 1. Steps for deploying and maintaining a Lean Office

Seeking to improve the understanding of the method proposed, below is a brief description of the eight steps proposed by Tapping and Shuker (2010):

Step 1 - Commitment to Lean principles: Through encouraging teamwork, top management and all employees should support the Lean transformation effort.

Step 2 - Choice of the value stream: The choice of the value stream to be mapped must take into account, in addition to individual processes, also the previous and later processes that shall be impacted. It is important to highlight the importance that the selected value stream must be related to the final client and be within the limits of the organization's installations.

Step 3 - Learning about Lean philosophy: the learning process about the Lean philosophy differs for each organization and it is necessary to explain Lean concepts and tools to workers. Each group of people represents a set of diverse knowledge. Therefore, the training plan must be adequate to these needs.

Step 4 - Mapping the current state: Mapping consists of a visual representation through symbols or icons of the material flow and information of a specific value stream. For a good mapping, one must observe and understand the value stream and start it at the point closest to the client and come back to the initial processes or activities of the value stream.

Step 5 - Identification of Lean performance measures: To determine a Lean metric that is effective, one should look for one that allows stratification in components that address waste identified. However, the metrics defined should be easy to understand and to collect the data.

Step 6 - Mapping the future state: One should critically analyze the map of the current state in order to solve problems detected, understanding the clients' demands. The plan to achieve the future state needs everyone's collaboration with ideas focused on an evolution process.

Step 7 - Creating the Kaizen plans: Processes must be modified to become better. Planning allows improvements to be achieved and efforts recognized.

Step 8 - Implementing Kaizen plans: no plan is perfect. And in seeking adequation and adjustments there are three steps to implementing Kaizen plans: preparation, implementation and follow-up. To 
succeed in Lean transformation in an organization, people must always seek ways to improve the value stream.

Now, the context of field research is presented. Eight implementation and maintenance stages of a Lean Office are suggested by Tapping and Shuker, (2010), previously illustrated. It should be noted that the term "case study" does not refer to the research method that consists of an in-depth and exhaustive study of one or a few objects, in a way that allows its ample and detailed knowledge (Gil, 2010).

The case studied has taken place at a company specialized in graphic design of packaging. The company has been conceived a little more than 10 years ago. The packaging development sector has several particularities and complexities since it involves, besides the graphic (visual) and the glyph (structural), the life cycle analysis, the stakeholders involved in the process (raw material converter, the designer, the packaging industry, product packaging, distribution, point of sale, final consumer and disposal) and its scope, extended beyond the primary functions of containing, protecting and transporting products, adding communication, financial and environmental aspects.

In order to position itself in the market, the company has specialized only in graphic design. Currently the office has 30 employees and serves large clients in domestic and international markets, having won several design and recognition awards in the market. The company's growth is constant. When a new multinational is conquered as a client, many projects are simultaneously demanded, which ends up overwhelming the team and unbalancing the workflow. This common scenario in communication agencies has motivated the company to agree to the development of this study and disseminated the idea among employees, thus fulfilling the first stage of the proposed methodology, which is the commitment with Lean principles.

After an initial survey that involved the observation of all sectors and the follow-up of requests from start to finish of the process, meetings and interviews with those involved in the operational and management processes, it was decided to map the process completely, thus defining the value stream to be studied, deepening the specific details of each area. Thus, the definition of the value stream has been established, fulfilling the second stage of the methodology. The implementation of the third stage was on learning about Lean principles, which presented many difficulties. The team was extremely involved in its work routines and the creative sector noticed some resistance because it believed that the creative process should not be standardized or formalized, with risks of inhibiting creative stimuli, which are indispensable for the company's survival in the market. This aspect can be considered a negative point in the implementation of the Lean Office Even after the initial meeting for the project, some people were suspicious of the work to be done and others did not answer questions due to an alleged lack of time.

Based on the information collected through informal conversations with all of the company's employees, from the directors to the receptionist, in a direct observation of routines and processes and also in the access to the computerized system that is responsible for much of the flow of information between the company's sectors and clients (most of them are from the southeastern region of Brazil or outside the country and packaging designs are delivered virtually), the current state map was designed, visually represented by the use of symbols and icons and identifying the flow of the material and the specific information of each stage. Figure 2 includes the fourth step of the methodology proposed. Representative symbologies used on the map are identified through legends located on the upper left side of the map.

The value stream map represents the entire path that a graphic packaging project runs through in its enterprise life cycle. It starts by the first contact with the client or possible client, usually by an designation. There is a generic value table where prices can be compounded, taking into account the level of complexity of the project, the urgency of delivery, the steps and suppliers involved, and an empirical execution time estimate. Before sending the commercial proposal to the client, the management must approve and it is not always that there is such immediate availability, taking into account that the number of trips for service is constant. This was the first point identified for possible improvement.

The yellow frames outlined by red dotted lines are the cyclic steps that can cause several rounds in the same process. The determining factor is the client's acceptance of the amount charged and the project itself. The creative process is intangible. And even if the packaging was designed based on market research, clients' perceptions directly influence the product final delivery. 
Value stream mapping (VSM)

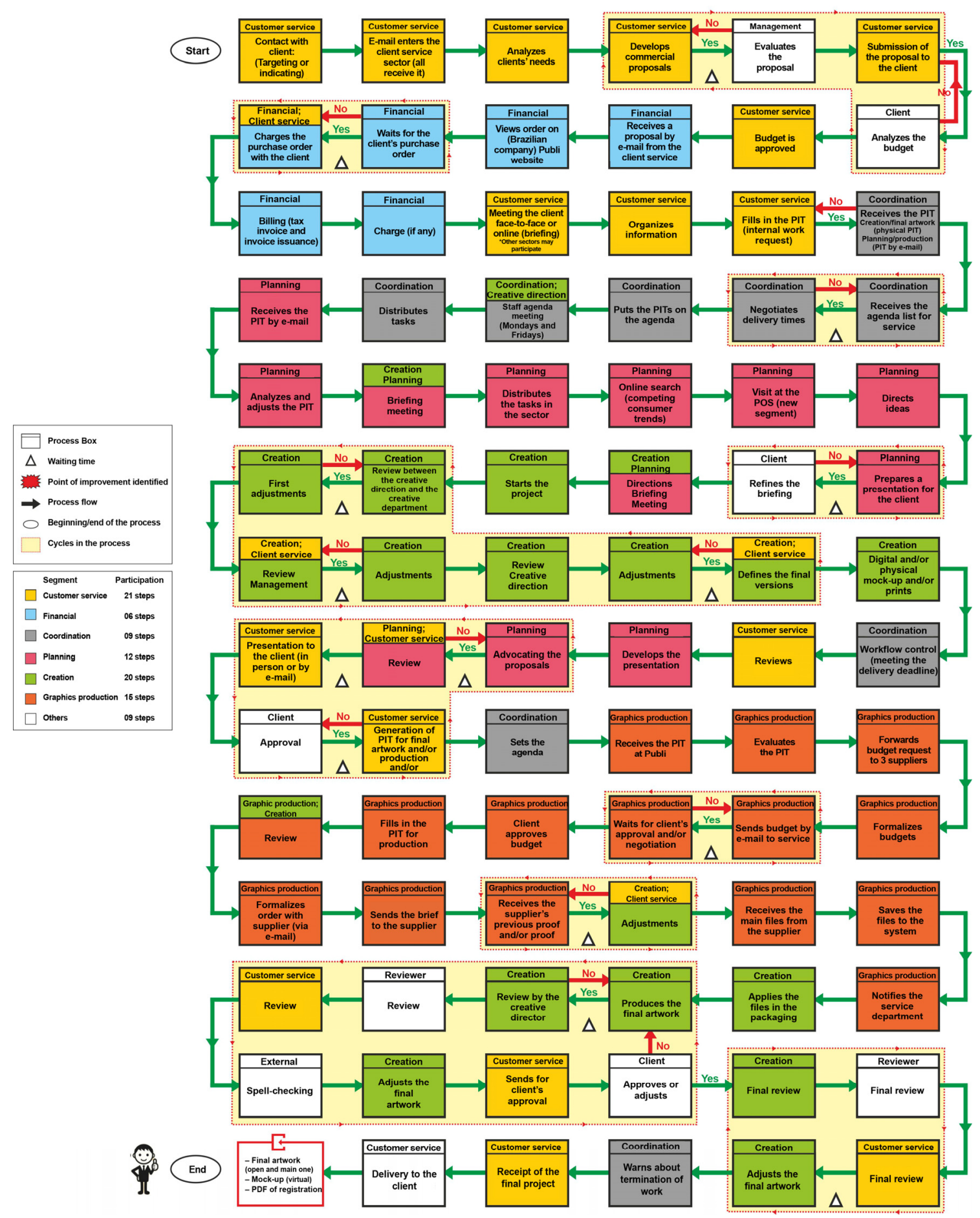

Figure 2. Complete value stream mapping (VSM)

The company does not have an accurate survey of the time at which the packaging goes through this process. There is an estimate based on the history of the orders executed. Usually it is the client who determines the deadline and the agency does the planning taking into account the date of final delivery. Figure 3 presents the workflow separated by the sectors and their independent tasks with an estimate of time by tasks, Lead time and the time of the complete takt time process. 


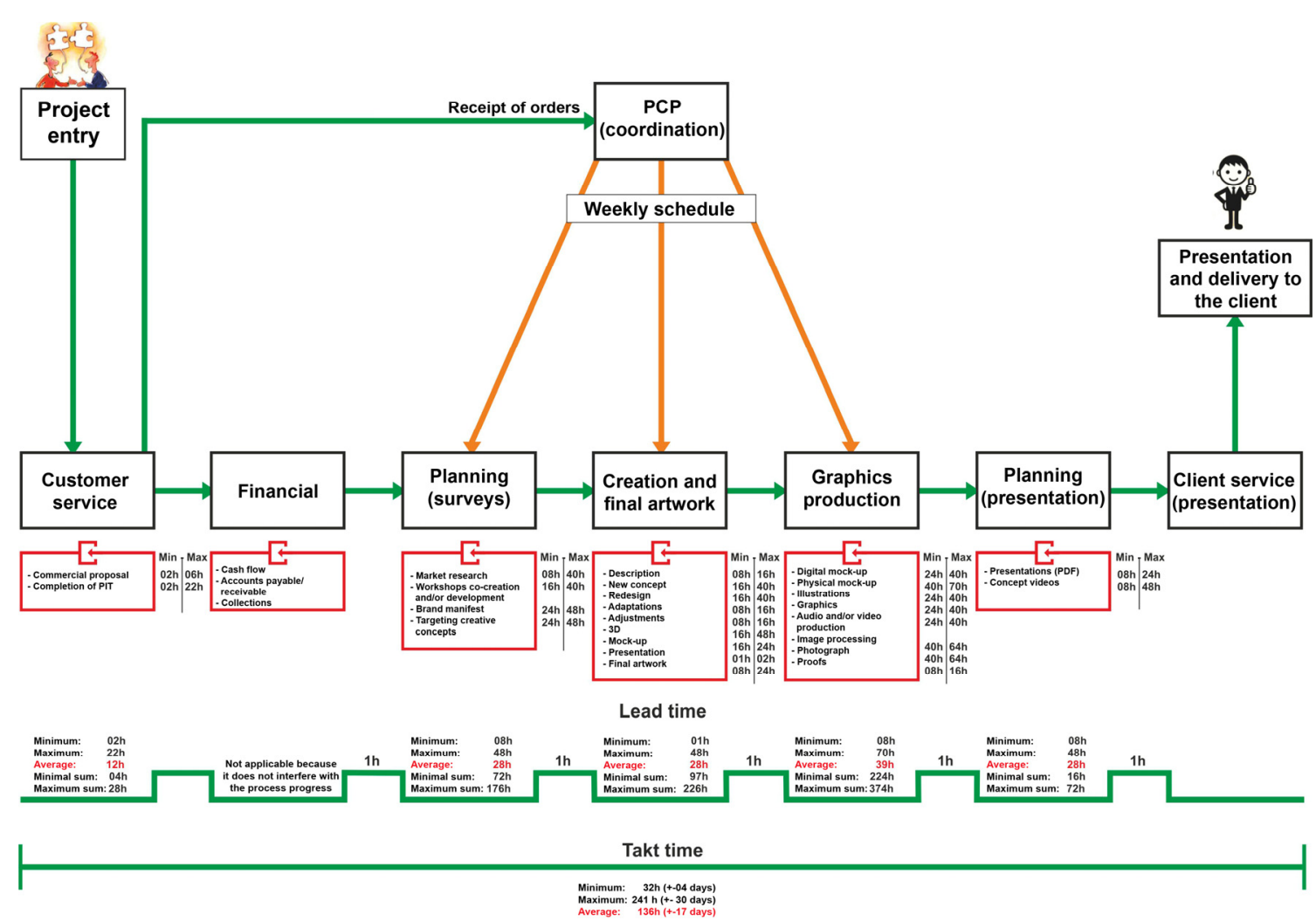

Figure 3. Stream mapping with time estimate

The coordination staff monitors order scheduling on a weekly basis and distributes the tasks in the company's core sectors. Although the focus is on packaging, project needs widely vary and each sector offers a range of tangible and intangible service possibilities, making it difficult to estimate the exact production time. Based on direct observation and monitoring of some projects, it was possible to estimate minimum, average and maximum times per task, the Lead time and, by the complete cycle, the takt time. Considering the tasks that take the least time for execution (one per sector), the minimum time for the complete execution of a package is 32 hours, approximately four working days, considering a working day of eight hours. The maximum time, considered by the sum of all possible tasks covered in all of the company's sectors, is 241 hours or approximately 30 business days. The average time was calculated by summing the minimum and maximum times of the tasks by sectors and dividing by two. The average takt time result was 136 hours, approximately seventeen business days.

It is possible to note that the execution time of a project is quite long, even in less complex situations, showing the importance of the present study regarding the visibility of bottlenecks and in proposing improvements to optimize the projects execution time. Points to be improved were flagged and numbered in chronological order and shall be discussed in the following Section through the Figure called waiting points and the Kaizen framework, identifying and delimiting Lean performance measures as compliance with the methodology fifth step.

\section{Discussion and results}

During the study of the case unit, discussed in the previous Section, it was possible to proceed and to comply with the preliminary steps from 1 to 5 of the methodology proposed by Tapping and Shuker (2010). Steps 6, 7 and 8 shall now be discussed, starting with the design of the map only with the process waiting points, i.e., the potential moments to be improved (Figure 4). The process improvement points, identified from 1 to 11 on this map, shall be commented on in the Kaizen chart, retrieving as support some of the 30 points of waste identified by Vidolin (2015), previously addressed in the literature review. 


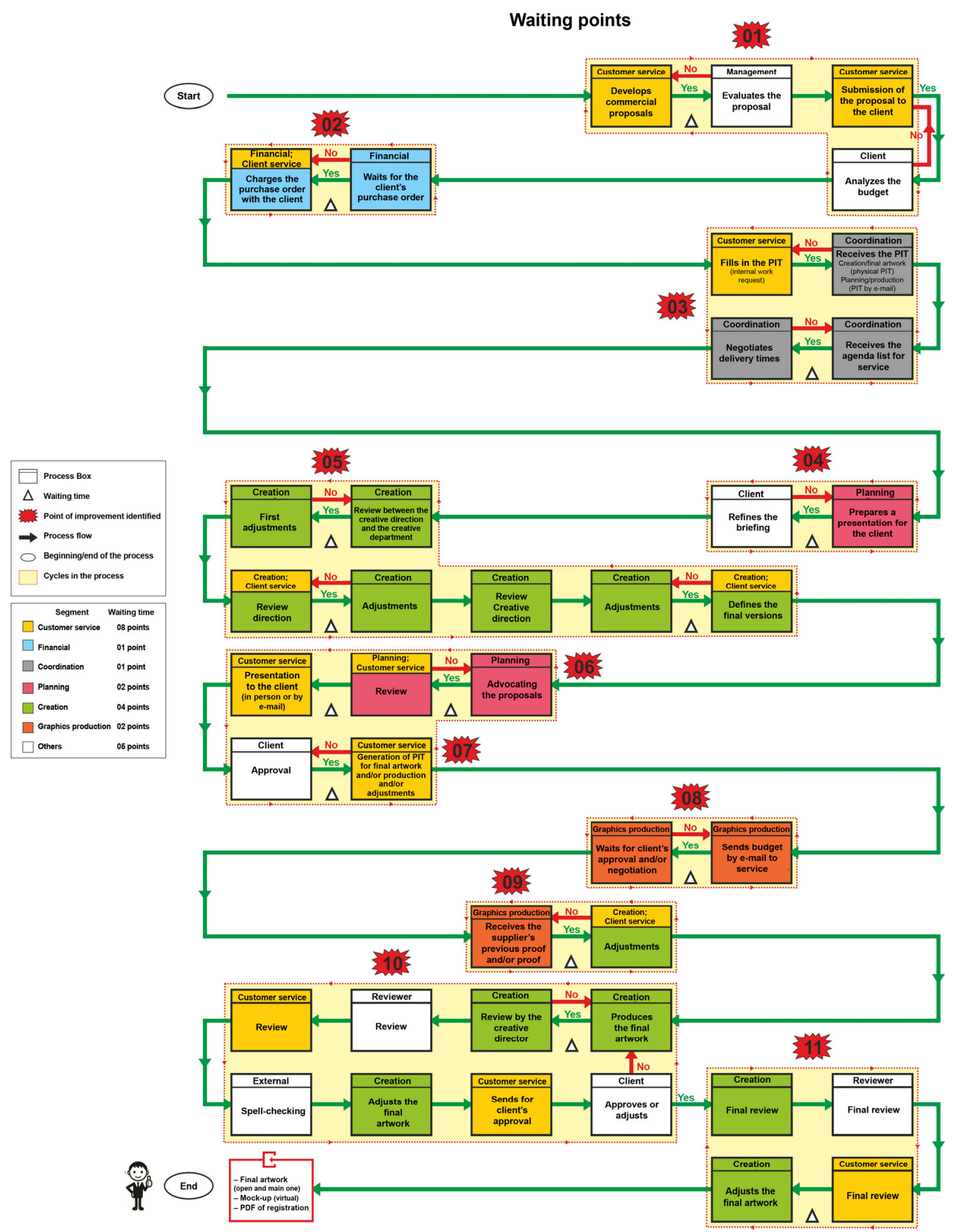

Figure 4. Waiting points identified in the value stream map

The legend located to the left of the Figure identifies the number of waiting points in which each sector participating in the process and the service sector is the one with the largest number of participations. The flagged points identify the number of times when the workflow may be interrupted or delayed. The impact and the improvement action in each of these points is presented through the Kaizen plan in (Table $3)$. 
Table 3. Proposing improvements - Kaizen chart

\begin{tabular}{|c|c|c|c|}
\hline $\mathbf{N}$ & Problem & Impact & Action \\
\hline 1 & Budget approval & $\begin{array}{l}\text { The client may delay the process or } \\
\text { may not close the order. }\end{array}$ & Being in line with clients' needs and funds. \\
\hline 2 & $\begin{array}{l}\text { Purchase order } \\
\text { for billing }\end{array}$ & Delaying billing and financial receipt. & Conditioning clients on formalizing orders. \\
\hline 3 & $\begin{array}{l}\text { Negotiation of } \\
\text { delivery period. }\end{array}$ & $\begin{array}{l}\text { Fail to meet deadline and/or } \\
\text { compromising the project quality. }\end{array}$ & $\begin{array}{l}\text { Having a previous estimate of production } \\
\text { time to have more negotiation support with } \\
\text { the client. }\end{array}$ \\
\hline 4 & $\begin{array}{l}\text { Refining the } \\
\text { briefing }\end{array}$ & $\begin{array}{l}\text { Understanding the clients' needs to } \\
\text { prevent the project from reaching the } \\
\text { end with problems. }\end{array}$ & $\begin{array}{l}\text { Being attentive to the details of the project, } \\
\text { as well as the correct completion of the } \\
\text { briefing. }\end{array}$ \\
\hline 5 & First review & $\begin{array}{l}\text { This stage has a high potential to delay } \\
\text { the process. }\end{array}$ & $\begin{array}{l}\text { Anticipating the project revision times and } \\
\text { scheduling with its stakeholders and/or } \\
\text { running virtual meetings in the event of } \\
\text { someone's absence. }\end{array}$ \\
\hline 6 & Second review & $\begin{array}{l}\text { This stage has a high potential to delay } \\
\text { the process. }\end{array}$ & $\begin{array}{l}\text { The good performance of the first review } \\
\text { can eliminate or reduce the duration of this } \\
\text { stage. }\end{array}$ \\
\hline 7 & $\begin{array}{l}\text { Presentation to } \\
\text { the client }\end{array}$ & $\begin{array}{l}\text { There is a risk of restarting the project } \\
\text { if the client does not approve it. }\end{array}$ & $\begin{array}{l}\text { Filling in the briefing correctly and } \\
\text { capturing the essence of the project from } \\
\text { the beginning. The service sector plays a } \\
\text { prominent role. }\end{array}$ \\
\hline 8 & $\begin{array}{l}\text { Graphics } \\
\text { production } \\
\text { approval }\end{array}$ & $\begin{array}{l}\text { This stage has a high potential to delay } \\
\text { the process. }\end{array}$ & $\begin{array}{l}\text { Filling in the briefing correctly and } \\
\text { capturing the essence of the project from } \\
\text { the beginning. }\end{array}$ \\
\hline 9 & $\begin{array}{l}\text { Adjusting third- } \\
\text { party materials }\end{array}$ & $\begin{array}{l}\text { This stage has a high potential to delay } \\
\text { the process. }\end{array}$ & $\begin{array}{l}\text { Scheduling in advance the project entry and } \\
\text { detailing as much as possible the demand } \\
\text { to avoid rework or delay in delivery. }\end{array}$ \\
\hline 10 & $\begin{array}{l}\text { Review of the } \\
\text { final artwork }\end{array}$ & $\begin{array}{l}\text { Due to involving several people, this } \\
\text { stage has a high potential to delay the } \\
\text { process. }\end{array}$ & $\begin{array}{l}\text { Having the correct information and } \\
\text { carefully reviewing to avoid client's } \\
\text { adjustments in your review. }\end{array}$ \\
\hline 11 & Final review & This step can generate rework. & $\begin{array}{l}\text { The good performance of the previous step } \\
\text { can eliminate or reduce the duration of this } \\
\text { stage. }\end{array}$ \\
\hline
\end{tabular}

The waiting points identified in the company's design processes have shown a degree of complexity because of their intangibility. Losses related to waiting between one stage and another in the process have been identified, as well as, in the relationship with outsourced services, lack of method and standardization in possible implementation processes, errors caused by irregular flow of tasks or unnecessary verifications in conducting information collected from clients. It was possible to realize that some steps can be avoided, (such as excessive reviews), when following the actions proposed in the Kaizen framework.An important contribution concerns the management behavior which, in addition to observing the workflow more closely, is open to proposals for improvements in the company.

\section{Conclusion}

The theoretical contribution of this study was the proposition and the use of systemic tools to promote improvements in an office that works in the area of creativity, which seems unlikely. Through the use of these tools, it was possible to verify the feasibility of using the tools in their practical application, contributing to promote benefits in the reduction of waste, optimizing the processes and reducing the delivery deadlines, increasing the profit margin of the company and also in proposing improvements in the process.

This study showed that in some areas of the company that require greater creativity, such as the creative and planning sector, systemic tools can repress the creative process, especially when the deadline for 
submission of works is reduced. The value stream map identifies these areas and enables the manager to apply the Lean Office in a personalized way.

The present study indicates the feasibility of implementing the Lean philosophy in creative companies, highlighting their adaptations and choice of criteria and evaluation tools, specially in the complexity of the use of time measurements criteria. As future studies, combining the use of other Lean tools is suggested, mainly with regard to time measurement and also extending to other creative sectors such as architecture offices, advertising agencies, product design studios, consultancies, among others.

\section{References}

Cavaglieri, M. and Juliani, J.P. (2016a), "Lean archives: The use of Lean Office in archive management", Perspectivas em Ciência da Informação, Vol. 21 No. 4, pp. 180-201. https://doi.org/10.1590/1981-5344/2726

Cavaglieri, M. and Juliani, J.P. (2016b), "Implantação do sistema kanban como instrumento de controle dos documentos", ÁGORA, Vol. 25 No. 52, pp. 119-142.

Danielsson, C. (2013), "An explorative review of the Lean office concept", Journal of Corporate Real Estate, Vol. 15 No. 3-4, pp. 167-180. https://doi.org/10.1108/JCRE-02-2013-0007

Evangelista, C., Grossi, F. and Bagno, R. (2015), "Lean Office - escritório enxuto: estudo da aplicabilidade do conceito em uma empresa de transportes", Revista produção e engenharia, Vol. 5 No. 1, pp. 462-471.

Gil, A.C. (2010), Como elaborar projetos de pesquisa, 5th ed., Atlas, São Paulo.

Gupta, S., Sharma, M. and Vijaya, S. (2016), "Lean services: a systematic review”, International Journal of Productivity and Performance Management, Vol. 65 No. 8, pp. 1025-1056. https://doi.org/10.1108/IJPPM-022015-0032

Hallam, C. and Contreras, C. (2016), "Integrating lean and green management", Management Decision, Vol. 54 No. 9, pp. 2157-2187. https://doi.org/10.1108/MD-04-2016-0259

Ishizaka, A.Y., Dinis, L.S., Watanabe, N.L., Sales, S.R. and Sagawa, J.K. (2016), "Lean Office: Uma aplicação no Departamento de Marketing de uma instituição financeira", Produto \& Produção, Vol. 17 No. 4, pp. 41-61.

Lopes, M.C. (2011), Melhoria de Processo sob a ótica do Lean Office, PhD Thesis, Universidade de São Paulo.

Ohno, T.O. (1997), Sistema Toyota de Produção: Além da produção em larga escala, Bookman, Porto Alegre.

Saurin, T., Marodin, G. and Ribeiro, J.A. (2011), "Framework for assessing the use of lean production practices in manufacturing cells", International Journal of Production Research, Vol. 49 No. 11, pp. 3211-3230. https://doi.org/10.1080/00207543.2010.482567

Silva, I. et al. (2015) "Lean office in health organization in the Brazilian Army", International Journal of Lean Six Sigma, Vol. 6 No. 1, pp. 2-16. https://doi.org/10.1108/IJLSS-09-2013-0053

Tapping, D. and Shuker, T. (2003), “Step 6-Phase I. Map the Future State - Customer Demand”, In: Tapping, D. and Shuker, T. (Eds.), Value Stream Management for the Lean Office Eight Steps to Planning, Mapping, \& Sustaining Lean Improvements in Administrative Areas, CRC Press, pp. 83-98.

Turati, R. and Musetti, M. (2006), "Aplicação dos conceitos de Lean Office no setor administrativo público", $X X V I$ ENEGEP, Fortaleza, CE, Brasil, October 9-11, 2006.

Vidolin, A.C. (2015), "Implementação do Lean Office: análise de estudos de casos", Revista Eletrônica SPEI.

Womack, J.P. and Jones, D.T. (2005), "Lean consumption”, Harvard business review, March 2005.

Womack, J.P. and Jones, D.T. (2010), Lean thinking: banish waste and create wealth in your corporation, Free Press, New York.

Ricardo Marques Sastre, Master in Design - Professor

Universidade Federal do Rio Grande do Sul - UFRGS, Departamento de engenharia de produção e transportes

Rua Duque de Caxias, 512 ap 302, 90010280 Porto Alegre, Brazil

Email: ricsastre@gmail.com 